\title{
1 Thermodynamics of $\mathrm{CeSiO}_{4}$ : Implications for Actinide Orthosilicates
}

2

3 Andrew C. Strzelecki ${ }^{1,2,3}$, Clement Bourgeois ${ }^{1,2}$, Kyle W. Kriegsman ${ }^{1,2}$, Paul Estevenon ${ }^{4,5}$, Nian $4 \mathrm{Wei}^{1,6}$, Stephanie Szenknect ${ }^{4}$, Adel Mesbah $^{4}, \mathrm{Di} \mathrm{Wu}^{1,2,3,7}$, Rodney C. Ewing ${ }^{8}$, Nicolas Dacheux $^{4}$, 5 Xiaofeng Guo ${ }^{1,2,3, *}$

6

$7{ }^{1}$ Department of Chemistry, Washington State University, Pullman, Washington 99164, United $8 \quad$ States

$9{ }^{2}$ Alexandra Navrotsky Institute for Experimental Thermodynamics, Washington State University, 10 Pullman, Washington 99164, United States

$11{ }^{3}$ Materials Science and Engineering, Washington State University, Pullman, Washington 99164, $12 \quad$ United States

$13{ }^{4}$ ICSM, Univ Montpellier, CNRS, CEA, ENSCM, Site de Marcoule - Bât. 426, 30207 Bagnols sur 14 Cèze, France

$15{ }^{5}$ CEA, DES, ISEC, DMRC, Univ Montpellier, Marcoule, France 16 17 18 19 20 21 22 23 $24 *$ e-mail:x.guo@wsu.edu 25

${ }^{6}$ College of Physical Science and Technology, Sichuan University, Chengdu 610065, People's Republic of China

${ }^{7}$ The Gene and Linda Voiland School of Chemical Engineering and Bioengineering, Washington State University, Pullman, Washington 99164, United States

${ }^{8}$ Department of Geological Sciences, Stanford University, Stanford, California 94305, United States 
TOC:

The mineral zircon $\left(\mathrm{ZrSiO}_{4}: \mathrm{I}_{1} / \mathrm{amd}\right)$ can accommodate natural actinides, such as thorium and uranium. The zircon structure has also been obtained for several of the end member compositions of other actinides, such as plutonium and neptunium. However, the thermodynamic properties of these actinide zircon structure-types are largely unknown due to the difficulties in synthesizing these materials and handling transuranium actinides. Thus, we have completed a thermodynamic study of cerium orthosilicate, stetindite $\left(\mathrm{CeSiO}_{4}\right)$, a surrogate of $\mathrm{PuSiO}_{4}$. For the first time, the standard enthalpy of formation of $\mathrm{CeSiO}_{4}$ was obtained by high temperature oxide melt solution calorimetry to be $-1971.9 \pm 3.6 \mathrm{~kJ} / \mathrm{mol}$. Stetindite is energetically metastable with respect to $\mathrm{CeO}_{2}$ and $\mathrm{SiO}_{2}$ by $27.5 \pm 3.1 \mathrm{~kJ} / \mathrm{mol}$. The metastability explains the rarity of the natural occurrence of stetindite and the difficulty of its synthesis. Applying the obtained enthalpy of formation of $\mathrm{CeSiO}_{4}$ from this work, along with those previously reported for $\mathrm{USiO}_{4}$ and $\mathrm{ThSiO}_{4}$, we developed an empirical energetic relation for actinide orthosilicates. The predicted enthalpies of formation of $\mathrm{AnSiO}_{4}$ are then made with a discussion of future strategies to efficiently immobilize $\mathrm{Pu}$ or minor actinides in the zircon structure.

Keywords: cerium orthosilicate; thermodynamics; enthalpy of formation; ceramic waste forms; rare earth minerals; actinide geochemistry; lanthanide geochemistry; stetindite 


\section{Introduction:}

The fate of actinides from spent nuclear fuel discharged from a reactors, the actinide-containing waste separated by chemical processing of nuclear fuels, and of plutonium from dismantled nuclear weapons has raised several daunting environmental issues ${ }^{1}$. Currently, many countries are investigating solid matrices in order to immobilize the actinides prior to permanent disposal ${ }^{2}$. The immobilization step is typically accomplished either by vitrification or cementation, while the permanent disposal is completed either by a deep-mined geologic repository or deep bore-hole ${ }^{3-5}$. The main concern with this strategy, is the long-term safety associated with a disposal system's integrity on time scales that range from thousands to hundreds of thousands of years ${ }^{6}$. The structural and chemical stability of ceramics has been ascertained by studies of minerals, such as garnet, pyrochlore, zircon, zirconolite, apatite and monazite $^{7-15}$ which are all known to be able to incorporate Th and U over geologic time scales that stretch well beyond a million years ${ }^{16}$. Thus, the use of these mineral structure "analogues" as potential ceramic-based waste hosts for the permanent immobilization of actinides and long lived fission products have been the subject of considerable research over the past several decades ${ }^{17-23}$.

Among the single-phase, one of the crystalline ceramic candidates for actinide immobilization is the mineral zircon $\left(\mathrm{ZrSiO}_{4} ; \mathrm{I}_{1} / \mathrm{amd}\right) .{ }^{13,14,24}$ This is a direct result of zircon being an extremely durable mineral with a high loading of actinides and lanthanides ${ }^{25}$. The durability of zircon is demonstrated through its high insolubility under a variety of geochemically relevant conditions ${ }^{26-28}$ (i.e. high P-T environments and highly saline brines), even retaining these properties of insolubility as it undergoes metamictization $^{13,23,25}$, and a high physical toughness as the mineral grains are shown to endure the abrasive nature of weathering and erosional processes ${ }^{29}$.

Furthermore, zircon has been reported to readily allow for the substitution of $\mathrm{Pu}$ into its structure and has been identified as a key mineral phase for Pu in the "lavas" at the Chernobyl Nuclear Power Plant ${ }^{21,30-33}$. The synthesis of a pure $\mathrm{Pu}$ endmember orthosilicate $\left(\mathrm{PuSiO}_{4}\right)$ possessing the zircon structure was reported in the literature by Keller in 1963 through hydrothermal synthetic techniques ${ }^{34}$, however questions still remain about the overall purity of this zircon and the extreme difficulty of such a synthesis ${ }^{35}$. Also, there could be an miscibility gap within the $(\mathrm{Zr}, \mathrm{Pu}) \mathrm{SiO}_{4}$ system, as is evidenced by the substitution of $\mathrm{Pu}$ into zircon becoming increasingly more difficult when exceeding $10 \mathrm{wt} \%$ $\mathrm{Pu}^{15,36,37}$. This is most likely attributed to the thermodynamically unfavorable formation of $\mathrm{PuSiO}_{4}$ from its binary oxides, $\mathrm{PuO}_{2}$ and $\mathrm{SiO}_{2}$, which also indicates the instability $\mathrm{Pu}$ introduces to the zircon structure for the following solid-solution reaction: $x \mathrm{Pu}^{4+}+\mathrm{ZrSiO}_{4} \rightarrow\left(\mathrm{Pu}_{(x)} \mathrm{Zr}_{(1-x)} \mathrm{SiO}_{4}\right)+x \mathrm{Zr}^{4+}$. This hypothesis is supported by the recent work by Estevenon et al. in 2020, where they found that the 
hydrothermal conditions under which a pure $\mathrm{PuSiO}_{4}$ may form are extremely limited, with $\mathrm{PuSiO}_{4}$ as the minor product and $\mathrm{PuO}_{2}$ and $\mathrm{SiO}_{2}$ being the major phases ${ }^{35}$. Thus, due to the challenge of obtaining pure $\mathrm{PuSiO}_{4}$ and the safety precautions in handling of transuranium bearing orthosilicates, our experiments were conducted on $\mathrm{CeSiO}_{4}$. Cerium was selected as the surrogate for $\mathrm{Pu}$, due to the similarity in structure, and the ionic radii of the A-site cations and chemical properties (i.e., multiple valence states) ${ }^{38-41} \cdot \mathrm{Ce}^{4+}$ in the eight-coordination environment has an ionic radius of $0.97 \AA$, which is very close to that of eight-coordinated $\mathrm{Pu}^{4+}(0.96 \AA)^{42}$, therefore Ce in the solid-state system can be used to simulate $\mathrm{Pu}$. Pure synthetic $\mathrm{CeSiO}_{4}$ has been successfully prepared by both direct and indirect hydrothermal methods in $2019^{43,44}$ and has been used for the thermodynamic study in this paper.

We have measured the thermodynamic property of $\mathrm{CeSiO}_{4}$ for the first time. The significance is two-fold. Firstly, it has been well accepted that an empirical thermodynamic relationship exists within isostructural ceramic materials ${ }^{45}$ that the enthalpy of formation $\left(\Delta H_{\mathrm{f}}\right)$ for the ceramic phase can be correlated with the ionic radii of metal cations ${ }^{46}$. Thus, given the measured $\Delta H_{\mathrm{f}}$ of orthosilicates, one may predict $\Delta H_{\mathrm{f}}$ of an unknown phase (i.e. $\mathrm{PuSiO}_{4}$ ) through linear extrapolations ${ }^{47}$. This methodology enables the evaluation of the impact of $\mathrm{Pu}$ and minor actinides to the zircon structure from a thermodynamic perspective. Previously, thermodynamic parameters for coffinite $\left(\mathrm{USiO}_{4}\right)$ and thorite $\left(\mathrm{ThSiO}_{4}\right)$, isostructural compounds to zircon, have been determined experimentally ${ }^{1,8,48}$. Coffinite was found to be metastable, as evidenced by its positive enthalpy of formation from oxides $\left(\Delta H_{\mathrm{f}, \mathrm{ox}}=25.6 \pm\right.$ $3.9 \mathrm{~kJ} / \mathrm{mol}^{48}$ ) measured by Guo et al. using the high temperature oxide melt solution calorimetry, and the positive Gibbs free energy of formation $\left(\Delta G_{\mathrm{f}, \mathrm{ox}}=20.6 \pm 5.2 \mathrm{~kJ} / \mathrm{mol}^{49}\right)$ determined by Szenknect $e t$ $a l$. from solubility studies. The metastability of coffinite directly explains the difficulty associated with its synthesis such that one cannot simply prepare coffinite by a conventional solid-state reaction ${ }^{50}$. However, thorite is relatively easier to synthesize by various solid-state and aqueous-chemistry methods ${ }^{51-54}$, despite of the ionic similarity in $\mathrm{Th}^{4+}(1.05 \AA)$ and $\mathrm{U}^{4+}(1.00 \AA)^{42}$, the less difficult synthesis is consistent with its negative value of $\Delta H_{\mathrm{f}, \mathrm{ox}},-6.4 \pm 5.7 \mathrm{~kJ} / \mathrm{mol}^{8}$. Additionally, Ferriss et al. in 2010 performed density functional theory (DFT) calculations ${ }^{37}$ to predict $\Delta H_{\mathrm{f}}$ of $\mathrm{CeSiO}_{4}, \mathrm{ThSiO}_{4}$, $\mathrm{USiO}_{4}$, and $\mathrm{PuSiO}_{4}$. The DFT results predict values in good agreement with those of $\mathrm{ThSiO}_{4}{ }^{8}, \mathrm{USiO}_{4}{ }^{48}$, and $\mathrm{CeSiO}_{4}$ from this work.

Secondly, the natural mineral occurrence of $\mathrm{CeSiO}_{4}$, stetindite, was discovered in 2009 in a granitic pegmatite in Norway ${ }^{55}$. However, there are no studies of its thermodynamic stability. Thus, the first determination of $\Delta H_{\mathrm{f}}$ for $\mathrm{CeSiO}_{4}$ provides a basis for understanding the geochemical factors leading to the formation of this relatively rare mineral. 


\section{Experimental Methods}

\subsection{Sample synthesis and characterization:}

$\mathrm{CeSiO}_{4}$ samples were synthesized by hydrothermal method from $\mathrm{Ce}(\mathrm{III})$-silicate solid

117 precursor according to the protocol described by Estevenon et al. ${ }^{44}$. A stoichiometric mixture of $118 \mathrm{CeO}_{2}($ Sigma Aldrich, particle size $<5 \mu \mathrm{m})$ and $\mathrm{SiO}_{2}$ (Sigma Aldrich, 10-20 nm) were 119 mechanically milled $(30 \mathrm{~Hz}, 1$ hour) with a Retsch MM 200 vibration mill mixer in a tungsten carbide milling vessel. This mixture was pelletized by uniaxial pressing under $5 \mathrm{MPa}$ at room temperature and then heated at $1350^{\circ} \mathrm{C}$ under reductive atmosphere $\left(\mathrm{Ar}-4 \% \mathrm{H}_{2}\right)$ to prepare A- $\mathrm{Ce}_{2} \mathrm{Si}_{2} \mathrm{O}_{7}$ (tetragonal system, space group $P 4_{1}$ ). $200 \mathrm{mg}$ of $\mathrm{A}-\mathrm{Ce}_{2} \mathrm{Si}_{2} \mathrm{O}_{7}$ was placed in contact with $4 \mathrm{~mL}$ of a $0.75 \mathrm{M} \mathrm{HNO}_{3}$ solution (prepared by dilution of ACS grade $70 \% \mathrm{HNO}_{3}$, Sigma Aldrich), the $\mathrm{pH}$ of that solution was then adjusted to 7.0 using freshly prepared $\mathrm{NaOH}$ solution (from ACS grade $\mathrm{NaOH}$ pellets, Sigma Aldrich). This mixture was hydrothermally treated for 7 days at $150^{\circ} \mathrm{C}$ under air atmosphere in a $23 \mathrm{~mL}$ Teflon lined Parr autoclaves. The final product was separated from the aqueous solution by centrifugation, washed twice with deionized water and once with ethanol and then dried overnight at $60^{\circ} \mathrm{C}$. The final $\mathrm{CeSiO}_{4}$ powder sample was well characterized by a multitude of different characterization techniques. A summary of the techniques and the resulting data are presented in the supplementary information (SI) to this manuscript, with a more detailed description of the characterization being found in our previous work of Estevenon et al. 2019 ${ }^{44}$. These techniques included XRD (Figure S1), FTIR (Figure S2), Raman (Figure S3), XANES (Figure S4), EXAFS (Figure S5) and SEM (Figure S6). The results of all of these techniques allows us to confirm that the material which was investigated through the calorimetric techniques utilized and presented in this study to be chemically $\mathrm{CeSiO}_{4}$, with all the Ce presented being tetravalent, and the overall structure to belong to the space group $14_{1} /$ amd .

\subsection{Thermogravimetric analysis coupled with differential thermal analysis (TGA-DTA):}

The TGA-DTA measurements were performed on a Setaram SetSYS 2400 thermogravimetric differential scanning calorimeter, where $\mathrm{CeSiO}_{4}$ was heated from $28^{\circ} \mathrm{C}$ to $1200^{\circ} \mathrm{C}$, with a heating rate of $10^{\circ} \mathrm{C} / \mathrm{min}$., under a flowing $\mathrm{N}_{2}$ atmosphere $(20 \mathrm{~mL} / \mathrm{min}$.). The temperature and sensitivity of the instrument was calibrated by heating indium, tin, lead, zinc, and aluminum across their fusion point repeatedly at the temperature change rates of 5, 10, 15, and $20^{\circ} \mathrm{C} / \mathrm{min}$. The signals of each phase transition were then calibrated against the known heats of 


\subsection{High temperature oxide melt solution calorimetry:}

The enthalpy of drop solution $\left(\Delta H_{\mathrm{ds}}\right)$ was directly measured by a Setaram AlexSYS-1000 Calvet-type calorimeter. The calibration of the instrument was conducted by performing transpose temperature drops using solid pieces of $\alpha-\mathrm{Al}_{2} \mathrm{O}_{3}$ and Pt. Powdered samples were hand pressed into pellets, with masses between 3-5 mg, and dropped from room temperature into a molten solvent of sodium molybdate $\left(\mathrm{Na}_{2} \mathrm{O} \cdot \mathrm{MoO}_{3}\right)$ contained in a Pt crucible at $700^{\circ} \mathrm{C}$. The calorimeter chambers were continuously flushed with $\mathrm{O}_{2}$ gas at a rate of $\sim 100 \mathrm{~mL} / \mathrm{min}$ in order to facilitate a constant gas environment above the solvent. The $\mathrm{Na}_{2} \mathrm{O} \cdot \mathrm{MoO}_{3}$ melt is slightly oxidative ${ }^{56,57}$ and will maintain a redox environment which will keep all of the dissolved $\mathrm{Ce}$ in melt as $\mathrm{Ce}^{4+}$. ${ }^{5-60}$ Flushing of $\mathrm{O}_{2}$ gas above the solvent also further aids in maintaining an oxidative solvent environment, by oxidizing any low-valence $\mathrm{Mo}$ to $\mathrm{Mo}^{+6}$. Further, the $\mathrm{Na}_{2} \mathrm{O} \cdot \mathrm{MoO}_{3}$ solvent dissolves refractory elements, such as $\mathrm{Ce}$, but is relatively chemically inert to silicon $(\mathrm{Si})^{48,58,60,61}$. Therefore, the solvent saturation method $^{62}$ was used for correctly accounting for the energy associated with the all $\mathrm{Si}$ in the stetindite. This was accomplished by saturating $15 \mathrm{~g}$ of $\mathrm{Na}_{2} \mathrm{O} \cdot \mathrm{MoO}_{3}$ with $100 \mathrm{mg}$ of silica gel prior to the experiments as the solvent will no longer dissolve any $\mathrm{SiO}_{2}$, but instead will precipitate out as cristobalite at $700^{\circ} \mathrm{C}$. All of the calibration and methodology employed in this study are further described in more detail in previous reports $11,48,58,62-65$. Associated

\section{Results \& Discussion}

\subsection{Thermogravimetric analysis coupled with differential thermal analysis (TGA-DTA):}

Thermogravimetric analysis (TGA) of $\mathrm{CeSiO}_{4}$ showed two mass losses (Figure 1). The first mass loss of $3.20 \%$ occurs from room temperature to $900^{\circ} \mathrm{C}$ and is associated with the removal of surface water and structural water. The water content of the synthetic $\mathrm{CeSiO}_{4} \mathrm{was}$ quantified from the TGA result leading to the chemical formula: $\mathrm{CeSiO}_{4} \cdot 0.43 \mathrm{H}_{2} \mathrm{O}$, which also resembles the hydrated form of synthetic $\mathrm{USiO}_{4}$ prepared by hydrothermal methods ${ }^{48}$. The origins and location of water within zircon structural materials has been highly debated in the literature ${ }^{17,52,66-71}$. The observation of a continual mass till $900^{\circ} \mathrm{C}$, shows that majority of the water associated with $\mathrm{CeSiO}_{4}$ is energetically strongly associated with the material, for merely adsorbed surficial water would leave the sample below $200^{\circ} \mathrm{C}$. This conclusion of strongly associated water is consistent with the previous observations of excess water associated with both natural and synthetic coffinite samples $\left(\mathrm{USiO}_{4}\right) .{ }^{17,48}$ However, the origins of such excess water in coffinite is 
not simple and still subject to debate as both infrared spectroscopic and X-ray diffraction studies have ruled out the water being structural ${ }^{17,52,66-70}$. One prevailing theory of how water is associated with natural zircons is in form of $\mathrm{OH}-$ and various $\mathrm{Zr}$ or Si related vacancies ${ }^{71}$. Such $\mathrm{OH}$ - groups would be evident in the $3000-3500 \mathrm{~cm}^{-1}$ IR region ${ }^{72}$ of which was not detected by FTIR (Figure S2) and would further require a charge substitution of $\mathrm{Ce}^{4+}$ to $\mathrm{Ce}^{3+}$, which was not present in the XANES spectra (Figure S4). Lastly, the EXAFS (Figure S5) of the material elucidates that the coordination environment of the elements is that of a zircon structural material, with no vacancies or $\mathrm{OH}$ - being found to contribute. A potential origin of water which is energetically strongly associated, but non-structural, and is not readily visible through FTIR or XRD could be as confined molecular water inside channels along the [001] in the zircon structure $^{17,70,73}$. This hypothesis offers an explanation for why the water is observed as molecular and not structural ${ }^{69}$.

The second mass loss $(2.17 \%)$ from $980-1110^{\circ} \mathrm{C}$ corresponds to $1 / 4$ of a mole of $\mathrm{O}_{2}$ being released in association with the reduction of $\mathrm{Ce}^{4+}$ to $\mathrm{Ce}^{3+}$ resulting in the cerium (III) disilicate phase, $\mathrm{A}-\mathrm{Ce}_{2} \mathrm{Si}_{2} \mathrm{O}_{7}$ under the inert atmosphere. This is further supported by the corresponding endothermic heat flow indicated by DTA. The decomposition temperature is much higher than $700^{\circ} \mathrm{C}$ at which the oxide melt solution calorimetry was conducted. Thus, we conclude that the decomposition has no bearing to the final thermochemical results.

\subsection{Enthalpy of formation of $\mathrm{CeSiO}_{4}$ :}

The hydrothermally prepared $\mathrm{CeSiO}_{4}$ sample used in this study exhibits a similar hydrated composition to that of the analogous synthetic $\mathrm{USiO}_{4}$ prepared by similar hydrothermal techniques $^{48,74}$. To ensure the quality of the obtained enthalpy of formation, we followed the previously developed methodology for hydrated minerals (e.g., coffinite $^{48}$ ) and performed two sets of high-temperature oxide melt solution calorimetry experiments. The first set of these experiments were performed using the sample as is, with a chemical formula of $\mathrm{CeSiO}_{4} \cdot 0.43 \mathrm{H}_{2} \mathrm{O}$. Through these experiments the enthalpy of drop solution $\left(\Delta H_{\mathrm{ds}}\right)$ of $\mathrm{CeSiO}_{4} \cdot 0.43 \mathrm{H}_{2} \mathrm{O}$ was found to be $95.36 \pm 3.52 \mathrm{~kJ} / \mathrm{mol}$ (Table 1). The second set of experiments was done after the sample was fully dehydrated. The dehydration of the sample was accomplished by heating pelletized samples (3-5 mg) for two hours under an inert atmosphere of $\mathrm{N}_{2}$ to $800^{\circ} \mathrm{C}$. Samples were then stored at room temperature under a $\mathrm{N}_{2}$ atmosphere prior to being dropped in order to avoid any potential water re-adsorption. All of the experimental parameters and materials exactly mirrored those utilized for the hydrated sample outlined above in the methods sections. The resulting enthalpy of 
drop solutions determined by these experiments was $\Delta H_{\mathrm{ds}}=92.88 \pm 3.40 \mathrm{~kJ} / \mathrm{mol}$ (Table 1), slightly less endothermic than that from the first experiment. This is reasonable because the thermal dehydration leads to the positive contribution to the $\Delta H_{\mathrm{ds}}$ value. However, the difference, $2.48 \mathrm{~kJ} / \mathrm{mol}$, is unexpectedly small. The small hydration enthalpic value could be due to the partial dehydration of $\mathrm{CeSiO}_{4} \cdot 0.43 \mathrm{H}_{2} \mathrm{O}$ during dropping before it reached the reaction chamber where the measurements were taken. AlexSYS-1000 has an inhomogeneous temperature profile, with over $60 \mathrm{~cm}$ above the reaction chamber maintaining at around $650^{\circ} \mathrm{C}$. Rapid dehydration could occur, ${ }^{75,76}$ and the composition of the resulting sample detected by the thermopiles was estimated from the TGA result to be $\mathrm{CeSiO}_{4} \cdot 0.025 \mathrm{H}_{2} \mathrm{O}$.

The $\Delta H_{\mathrm{ds}}$ for such partially hydrated sample must be then corrected in order to account for the additional energetics related with the associated water. As it was stated above, it is reasonable to assume that a portion of water is strongly bonded to $\mathrm{CeSiO}_{4}$ as the TGA data showed an extended mass loss till $900^{\circ} \mathrm{C}$. Using an integral adsorption enthalpy of $-80 \mathrm{~kJ} / \mathrm{mol}$ per mol of $\mathrm{H}_{2} \mathrm{O}$ (-44 kJ/mol for "free water") for the adsorbed water, which was observed in the alumina and titania $^{77-79}$ and used for estimating hydration energy of coffinite ${ }^{48}$, one may derive the corrected $\Delta H_{\mathrm{ds}}$ for anhydrous $\mathrm{CeSiO}_{4}$ to be $88.7 \pm 3.4 \mathrm{~kJ} / \mathrm{mol}$ and $\Delta H_{\mathrm{f}, \text { ox }}$ to be $29.2 \pm 3.5 \mathrm{~kJ} / \mathrm{mol}$ (Table 1). While the direct measurement of anhydrous $\mathrm{CeSiO}_{4}$ yields $\Delta H_{\mathrm{f} \text {, ox }}$ of $25.0 \pm 3.5 \mathrm{~kJ} / \mathrm{mol}$ (Table 1),

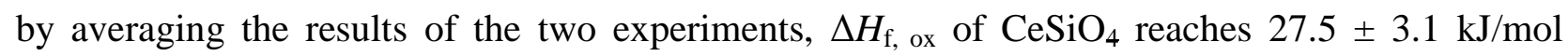
(Table S1), which is in excellent agreement with the DFT predicted value, $23.8 \mathrm{~kJ} / \mathrm{mol}^{37,63}$. With all of the evidence supporting that water is energetically strongly associated with stetindite, we report that $\Delta H_{\mathrm{f}}^{\circ}=-1971.9 \pm 3.6 \mathrm{~kJ} / \mathrm{mol}$, which is first reported standard enthalpy of formation data of stetindite (Table S1).

\subsection{Energetic Landscape of End-Member Actinide orthosilicates:}

Several empirical methodologies were developed for the prediction thermodynamic parameters of ceramic compounds. For instance, Chen et al. discovered that both the Gibbs free energies $\left(\Delta G_{f}\right)$ and enthalpies of formation $\left(\Delta H_{f}\right)$ of hexavalent uranium minerals could be predicted through the structural-summation technique. ${ }^{80}$ Whereas, Sverjensky and Molling ${ }^{45}$ established an empirical linear relationship between the free energy of isostructural inorganic solids and the ionic radii of aqueous metal cations. While this model was originally developed for divalent cations the model has been expanded to include tetravalent cations and its application allowed for the free energies of crystalline solids to be estimated by only having experimental data on a few samples. ${ }^{81,82}$ A very similar empirical linear relationship has been recognized for 
241

242

243

244

245

246

247

248

249

250

251

252

253

254

255

256

257

258

259

260

261

262

263

264

265

266

267

268

269

270

271

272

isostructural inorganic compounds which links the enthalpies of formation with the ionic radii of metal cations. ${ }^{46}$ Many lanthanide and actinide bearing isostructural ceramic materials follow this empirical trend and it has been applied numerous times in the literature ${ }^{47,64,83-85}$.

By using the experimentally determined $\Delta H_{\mathrm{f}, \text { ox }}$ of $\mathrm{CeSiO}_{4}(27.5 \pm 3.1 \mathrm{~kJ} / \mathrm{mol}), \mathrm{USiO}_{4}(25.6$ $\left.\pm 3.9 \mathrm{~kJ} / \mathrm{mol}^{48}\right)$ and $\mathrm{ThSiO}_{4}\left(-6.4 \pm 5.7 \mathrm{~kJ} / \mathrm{mol}^{8}\right)$ and the ionic radii $(\AA)$ of metal cations in an eight-fold coordination environment ${ }^{42}$, a near linear trend is found between $\Delta H_{\mathrm{f}, \text { ox }}$ and the ionic radius $r(\AA), \Delta H_{\mathrm{f}}$, ox $=(-446.3 \pm 152.5) r-(464.9 \pm 153.6)$, with an adjusted $R^{2}=0.79096$. From the obtained linear regression, we obtained the $\Delta H_{\mathrm{f}}$, ox for the other actinide $(\mathrm{Pa}, \mathrm{Np}, \mathrm{Pu}, \mathrm{Am}, \mathrm{Cm}, \mathrm{Bk}, \mathrm{Cf})$ orthosilicates (Figure 2). The heavier transuranic elements ( $\mathrm{Am}, \mathrm{Cm}, \mathrm{Bk}$, and $\mathrm{Cf}$ ) show more lanthanide-like characteristics, thus prefer having a trivalent oxidation state ${ }^{86-88}$. The trivalent oxidation would result in different ionic radii and preferred coordination chemistry ${ }^{89,90}$. In order for such trivalent cations to be introduced into the zircon structure a charge-coupled substitution would be required. Nonetheless, the tetravalent states of all the aforementioned elements are possible through either a transient state as a result of radiation-induced radiolysis ${ }^{91-93}$ or a steady state being stabilized by either ligands or electrochemical methods ${ }^{88,94-96}$. Each of these states, the transient state and steady state conditions, are achievable in the unlikely event of a failure of the geological repository and breach in radiological waste canister. Each of these states could be observed under such a hypothetical scenario, if said geological repository is located in a geologic setting where the host lithology is also rich with mineral halides (i.e. halite), such as what is observed at the Waste Isolation Pilot Plant (WIPP) located in New Mexico, U.S.A. ${ }^{97,98}$, then there would be a supply of radiation, heat, high ionic-strength aqueous solutions $^{99}$, and silica source from the bentonite backfill ${ }^{100}$. This could cause for the dissolution of another ceramic waste form and allow for the formation of an actinide orthosilicate, with such hypothetical conditions being similar to those used in synthesizing $\mathrm{PuSiO}_{4}{ }^{35}$. These actinide orthosilicate could form as colloid allowing for them to be transported immense distances ${ }^{101-103}$. Thus, here we consider the possible tetravalent states of these heavy transuranic elements and their potential impact to the structural stability.

As the thermodynamic stability of any given material is dictated by $\Delta G_{f}$, one needs $\Delta G_{f}=\Delta H_{f^{-}}$ $\mathrm{T} \Delta S_{f}$, with knowing the appropriate entropy $\left(\Delta S_{f}\right)$ value besides $\Delta H_{f}$, in order to evaluate the overall stability. However, under the standard condition $\left(\mathrm{T}=25^{\circ} \mathrm{C}, \mathrm{P}=1 \mathrm{Bar}\right)$, the entropic term is small. This is evidenced taking coffinite as an example. $\Delta G_{f}$ of coffinite was determined through solubility studies to be $-1867.6 \pm 3.2 \mathrm{~kJ} / \mathrm{mol}^{49}$ and its $\Delta H_{f}$ was determined by high temperature drop oxide melt calorimetry to be $=-1970.0 \pm 4.2 \mathrm{~kJ} / \mathrm{mol}^{48}$. At $25^{\circ} \mathrm{C}$, $\mathrm{T} \Delta S_{f}$ equal to -0.344 
$273 \mathrm{~kJ} / \mathrm{mol} \cdot \mathrm{K} \times 298.15 \mathrm{~K}=102.6 \mathrm{~kJ} / \mathrm{mol}$. Hence, under the standard condition enthalpy alone can be 274 used to approximately discuss the stability of actinide orthosilicates and represent the energetic 275 landscape (Figure 2). The regression of measured $\Delta H_{\mathrm{f} \text {, ox }}$ leads to an almost linear trend. The 276 extrapolated results based on such linear trend are in good agreement with those reported in a previous 277 computational study ${ }^{37}$. The result of the linear regression is summarized in Table 2 and plotted in 278 Figure 2. Only $\mathrm{ThSiO}_{4}$ has a negative formation enthalpy $(-6.4 \pm 5.7 \mathrm{~kJ} / \mathrm{mol})^{8}$, while all others are 279 expected to be thermodynamically metastable with respect to their binary oxides $\left(\mathrm{AnO}_{2}\right.$ and $\left.\mathrm{SiO}_{2}\right)$. 280 The favorable formation of $\mathrm{ThSiO}_{4}$ could be a result of its lowest ionic potential $(\mathrm{Z} / \mathrm{r})$ of 3.81 that 281 allows $\mathrm{Th}^{4+}$ to be stabilized in the zircon structure. Whereas, $\mathrm{USiO}_{4}, \mathrm{CeSiO}_{4}$, and $\mathrm{PuSiO}_{4}$ having 282 larger ionic potentials of 4.00,4.12, and 4.17, respectively, and thus can destabilize the zircon 283 structure. Said that, $\Delta H_{\mathrm{f}, \mathrm{ox}}$ of $\mathrm{ThSiO}_{4}$ does follow the linear trend established in this work and does not exhibit as an exception to the general rule.

The prediction in Figure 2 are consistent with the reported difficulty in synthesizing pure

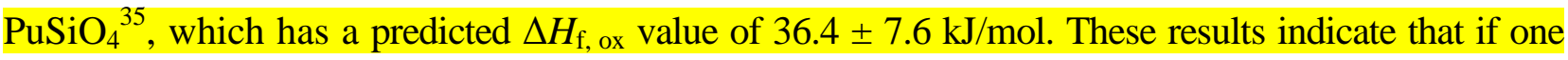
plans to use the zircon structure for immobilizing $\mathrm{Pu}$ or other minor actinides, they need to target synthesis strategies which disfavor the formation of binary oxides. As both coffinite and stetindite are found to have positive $\Delta H_{\mathrm{f}, \mathrm{ox}}$, the synthetic conditions of their formations could be highly informative for such strategies. Both of them have been discovered in nature under hydrothermal conditions and their synthetic analogs have been prepared by tailoring synthetic routes to avoid the formation of 292 thermodynamically more favorable binary oxides ${ }^{43,44,50,53,104}$. In particular the formation of stetindite 293 under laboratory conditions ${ }^{43,44}$, as the kinetics needed in order to oxidize either the $\mathrm{Ce}^{3+}$ intermediate complex ${ }^{43}$ or $\mathrm{Ce}^{3+}$ solid ${ }^{44}$, into the $\mathrm{Ce}^{4+}$ solid were only stable under hydrothermal conditions. In addition, taking the $\Delta H_{\mathrm{f} \text {, ox }}$ calculated through the linear regression, we also report the predicted $\Delta H_{\mathrm{f}}^{\circ}$ values for $\mathrm{PaSiO}_{4}, \mathrm{NpSiO}_{4}, \mathrm{PuSiO}_{4}, \mathrm{AmSiO}_{4}$ and etc. (Table 2) by using $\Delta H_{\mathrm{f}}^{\circ}$ of the respected $\mathrm{AnO}_{2}{ }^{105}$ as the auxiliary data. The overall $\Delta H_{\mathrm{f} \text {, ox }}$ is shown to be thermodynamically unfavorable for the major transuranic elements, $\mathrm{Np}, \mathrm{Pu}, \mathrm{Am}$, and $\mathrm{Cm}$. Nevertheless, Am-orthosilicate has been successfully synthesized and reported by Keller in $1963,{ }^{34}$ which make $\mathrm{CmSiO}_{4}$ also highly possible to exist because of their almost identical predicted formation enthalpies.

The zircon structure-type includes other crystalline ceramics and mineral orthosilicates. The 302 lanthanide orthovanadate $\left(\mathrm{LnVO}_{4}\right)$ minerals wakefieldite and dreyerite, the heavy rare earth 303 orthophosphate $\left(\mathrm{HREEPO}_{4}\right)$ mineral xenotime, and the lanthanide orthoarsenate $\left(\mathrm{LnAsO}_{4}\right)$ mineral 304 chernovite all share the zircon structure ${ }^{17}$. As the orthophosphate and orthovanadate materials 
enthalpies of formation have been reported in the literature ${ }^{59,106}$, they were also included in Figure 2 in order to detect any other trends across the isostructural family. This led to another important observation of the energetic landscape of orthosilicates in that both zircon and hafnon $\left(\mathrm{HfSiO}_{4}\right)$ are "outliers" of the predicted trend. We hypothesize that there could be a separate trend for transitional metal orthosilicates due to the structural difference that both of $\mathrm{Zr}^{4+}$ and $\mathrm{Hf}^{4+}$ are smaller cations $(0.84 \AA$ and $0.83 \AA$, respectively). This is further supported by both of these materials following the orthovanadate trend line, which are comparable in both energetics and unit cell volume to $\mathrm{ScVO}_{4}$. $\mathrm{This}$ observation, however, does not exclude the possibility of zircon and hafnon being outliners as a result of the fundamental bonding difference in $d$-orbitals $v s$. $f$-orbitals ${ }^{107}$. Lastly, these two trends for transition metal and lanthanide/actinide orthosilicates disagree with the previously reported actinide orthosilicate energetic landscape ${ }^{108}$. The discrepancy is attributed to an inaccuracy of $\Delta H_{\mathrm{ds}}$ for thorite as a result of incomplete dissolution of the single crystal sample and the inconclusive $\Delta H_{\mathrm{ds}}$ for coffinite in the early experiments, which we have discussed in a previous work ${ }^{48}$. The experimentally derived energetic trend fully agrees with the calculated values reported by the DFTLDA study ${ }^{37}$ (Figure 2), which likewise shows that both zircon and hafnon deviate from the linear trend.

\subsection{Strategic analysis of immobilizing Pu or other actinides in zircon structure:}

Although the pure actinide orthosilicate endmembers were calculated to have a positive $\Delta H_{\mathrm{f} \text {, ox }}$, it should be investigated whether any intermediate compositions from $\mathrm{MSiO}_{4}(\mathrm{M}=\mathrm{Zr}, \mathrm{Hf})$ and $\mathrm{AnSiO}_{4}(\mathrm{An}=\mathrm{Th}, \mathrm{U}, \mathrm{Np}, \mathrm{Pu}$, etc. $)$ endmembers can lead to thermodynamically favorable solid solutions for waste form applications. Using $\mathrm{MSiO}_{4}$-based solid solutions to strategically accommodate actinides has advantages in two different ways. Firstly, it may allow for easier synthesis of actinide-containing orthosilicates, as there could be a potential for short-range cation ordering that could significantly lower the enthalpic penalty for introducing $\mathrm{An}^{4+}$ into $\mathrm{ZrSiO}_{4}$. Such a phenomenon has already been demonstrated in uranothorite solid solution $\left(\mathrm{Th}_{1-x} \mathrm{U}_{x} \mathrm{SiO}_{4}\right)$, where the intermediate compositions are stabilized by a negative heat effect of $-118.7 \mathrm{~kJ} / \mathrm{mol}^{8}$. Secondly, the application of $\mathrm{HfSiO}_{4}$ as the endmember, instead of $\mathrm{ZrSiO}_{4}$, can offer an additional benefit to the waste form as hafnium is a neutron absorber ${ }^{14,19}$. The soft hydrothermal synthesis of hafnon could easily be modified to incorporate tetravalent actinides ${ }^{109}$. This soft hydrothermal synthetic technique could also be scalable for industrial application ${ }^{110}$. Unfortunately, the introduction of hafnium as a neutron absorber does not imply a reduction in the susceptibility to radiation damage ${ }^{21}$, a topic that has been extensively studied in the past ${ }^{31,111-116}$ and is still one of 
337

the greatest challenges to the utilization of zircon-based ceramic as a nuclear waste host. However, the introduction of hafnium could allow the incorporation of higher loadings of radionuclides with high specific activity (e.g. plutonium and americium isotopes) in the waste form without any worry of possible criticality ${ }^{15}$.

\section{Conclusions}

Through thermogravimetric analysis, differential thermal analysis (TGA-DTA), and high temperature oxide melt solution calorimetry, the thermodynamic parameters of stetindite $\left(\mathrm{CeSiO}_{4}\right)$ were determined. The results of the TGA-DTA show that $\mathrm{CeSiO}_{4}$ is hydrated, similar to that of $\mathrm{USiO}_{4}{ }^{48}$. By performing high temperature oxide melt solution calorimetry on $\mathrm{CeSiO}_{4}$, we determined its enthalpy of formation to be $\Delta H_{\mathrm{f}, \mathrm{ox}}=27.5 \pm 3.1 \mathrm{~kJ} / \mathrm{mol}$, confirming its metastability with respect to its binary oxides. The strong endothermic heat of formation accounts for the difficulty in synthesizing this phase in addition to the overall rarity of stetindite in nature. The overall enthalpy of formation was found to be thermodynamically favorable: $\Delta H^{\circ}{ }_{\mathrm{f}}=-1971.9 \pm 3.6$ $\mathrm{kJ} / \mathrm{mol}$. Exploiting the empirically derived linear trend between the enthalpy of formation and the ionic cation radius enabled the prediction of $\Delta H_{\mathrm{f}}^{\circ}$ of some unknown actinide silicates $\mathrm{AnSiO}_{4}(\mathrm{An}$ $=\mathrm{Np}, \mathrm{Pu}, \mathrm{Am}, \mathrm{Cm}, \mathrm{Bk}$, and $\mathrm{Cf}$ ). These high endothermic formation enthalpies provide an explanation for the difficulties in their synthesis, particularly the attempts to obtain pure $\mathrm{PuSiO}_{4}$, which was encountered by Estevenon et al. ${ }^{35}$ using hydrothermal methods. Indeed, it appears to be difficult according to a predicted value of $\Delta H_{\mathrm{f} \text {, ox }}=36.4 \pm 7.6 \mathrm{~kJ} / \mathrm{mol}$. Furthermore, the synthesis of minor actinides possessing the zircon structure, such as $\mathrm{AmSiO}_{4}$, should be even more difficult to synthesize as they are all found to be more energetically uphill than $\mathrm{PuSiO}_{4}$, with all being estimated to have $\Delta H_{\mathrm{f}, \text { ox }}>40 \mathrm{~kJ} / \mathrm{mol}$. Lastly, we propose that some $\mathrm{Zr}$-An or Hf-An orthosilicate systems may be thermodynamically favored by possible negative mixing enthalpies due to the short-range ordering of the two metal cations that can be engineered to increase the loadings of actinides in the zircon or hafnon structure-type, which have a relatively large stability field.

\section{Acknowledgements}

This work was supported by the institutional funds from the Department of Chemistry at Washington State University. A.C.S., K.W.K, and X.G. acknowledge the support by the U.S. Department of Energy, Office of Nuclear Energy, grant DE-NE0008582. C.B. acknowledges the fellowship provided by Setaram, Inc. for conducting the calorimetric research at WSU. Portions of 
369 this research were also supported by collaboration, services, and infrastructure through the 370 Nuclear Science Center User Facility at WSU and the WSU-PNNL Nuclear Science and 371 Technology Institute. 


\section{Tables}

373

374 Table 1 Thermochemical cycles used for calculations of the enthalpy of formation from binary 375 oxides and the standard enthalpy of formation of stetindite based on the data of drop solution 376 calorimetry in molten sodium molybdate saturated with amorphous silica at $25^{\circ} \mathrm{C}$.

\begin{tabular}{lc}
\hline Reaction & $\Delta H(\mathrm{~kJ} / \mathrm{mol})$ \\
\hline$(1) \mathrm{CeSiO}_{4} \cdot 0.43 \mathrm{H}_{2} \mathrm{O}_{\left(\mathrm{s}, 25^{\circ} \mathrm{C}\right)} \rightarrow \mathrm{CeO}_{2\left(\text { sln, } 700^{\circ} \mathrm{C}\right)}+\mathrm{SiO}_{2\left(\text { cristobalite, } 700^{\circ} \mathrm{C}\right)}+0.43 \mathrm{H}_{2} \mathrm{O}_{\left(\mathrm{g}, 700^{\circ} \mathrm{C}\right)}$ & $\Delta H_{1}=95.36^{*} \pm 3.52^{\dagger}(3)^{\ddagger}$ \\
$(2) \mathrm{CeSiO}_{4\left(\mathrm{~s}, 25^{\circ} \mathrm{C}\right)} \rightarrow \mathrm{CeO}_{2\left(\text { sln, } 700^{\circ} \mathrm{C}\right)}+\mathrm{SiO}_{2\left(\text { cristobalite, } 700^{\circ} \mathrm{C}\right)}$ & $\Delta H_{2}=92.88 \pm 3.40(2)$ \\
$(3) \mathrm{CeO}_{2\left(\mathrm{~s}, 25^{\circ} \mathrm{C}\right)} \rightarrow \mathrm{CeO}_{2\left(\text { sln, } 700^{\circ} \mathrm{C}\right)}$ & $\Delta H_{3}=74.37 \pm 0.75^{58}(66)$ \\
$(4) \mathrm{SiO}_{2\left(\text { quartz, } 25^{\circ} \mathrm{C}\right)} \rightarrow \mathrm{SiO}_{2\left(\text { (cristobalite, } 700^{\circ} \mathrm{C}\right)}$ & $\Delta H_{4}=43.54 \pm 0.60^{58}(3)$ \\
$(5) \mathrm{Ce}_{\left(\mathrm{s}, 25^{\circ} \mathrm{C}\right)}+\mathrm{O}_{2\left(\mathrm{~g}, 25^{\circ} \mathrm{C}\right)} \rightarrow \mathrm{CeO}_{2\left(\mathrm{~s}, 25^{\circ} \mathrm{C}\right)}$ & $\Delta H_{5}=-1088.7 \pm 1.5^{117}$ \\
$(6) \mathrm{Si}_{\left(\mathrm{s}, 25^{\circ} \mathrm{C}\right)}+\mathrm{O}_{2\left(\mathrm{~g}, 25^{\circ} \mathrm{C}\right)} \rightarrow \mathrm{SiO}_{2\left(q u a r t z, 25^{\circ} \mathrm{C}\right)}$ & $\Delta H_{6}=-910.7 \pm 1.0^{117}$ \\
$(7) \mathrm{H}_{2} \mathrm{O}_{\left(\mathrm{l}, 25^{\circ} \mathrm{C}\right)} \rightarrow \mathrm{H}_{2} \mathrm{O}_{\left(\mathrm{g}, 700^{\circ} \mathrm{C}\right)}$ & $\Delta H_{7}=69.0^{117}$ \\
$(8) \mathrm{H}_{2} \mathrm{O}_{\left(\mathrm{l}, 25^{\circ} \mathrm{C}\right)} \rightarrow \mathrm{H}_{2} \mathrm{O}_{\left(\mathrm{cr}, 25^{\circ} \mathrm{C}\right)}$ & $\Delta H_{8}=-80.0^{48}$
\end{tabular}

Enthalpy of drop solution corrected for proper molar mass of the partially hydrated sample:

(9) $\mathrm{CeSiO}_{4} \cdot 0.025 \mathrm{H}_{2} \mathrm{O}_{\left(\mathrm{s}, 25^{\circ} \mathrm{C}\right)} \rightarrow \mathrm{CeO}_{2\left(\sin , 700^{\circ} \mathrm{C}\right)}+\mathrm{SiO}_{\left.2 \text { (cristobalite, } 700^{\circ} \mathrm{C}\right)}+0.025 \mathrm{H}_{2} \mathrm{O}_{\left(\mathrm{g}, 700^{\circ} \mathrm{C}\right)}$

Corrected enthalpy of drop solution value assuming water is strongly bonded:

(10) $\Delta H_{\mathrm{ds}}\left(\mathrm{CeSiO}_{4}\right)=\Delta H_{10}=\Delta H_{9}-0.025 \cdot\left(\Delta H_{6}+\Delta H_{7}\right)$

$\Delta H_{\mathrm{ds}}=88.7 \pm 3.4$

Enthalpy of formation of stetindite from $\mathrm{CeO}_{2}$ and $\mathrm{SiO}_{2}$ (quartz) assuming water is strongly bonded:

(11) $\Delta H_{\mathrm{f}, \mathrm{ox}}\left(\mathrm{CeSiO}_{4}\right)=\Delta H_{11}=-\Delta H_{10}+\Delta H_{3}+\Delta H_{4}$

Standard enthalpy of formation of stetindite assuming water is strongly bonded

(12) $\Delta H_{\mathrm{f}}^{\circ}\left(\mathrm{CeSiO}_{4}\right)=\Delta H_{11}+\Delta H_{4}+\Delta H_{5}$

Enthalpy of formation of dehydrated stetindite from $\mathrm{CeO}_{2}$ and $\mathrm{SiO}_{2}$ (quartz):

(13) $\Delta H_{\mathrm{f}, \mathrm{ox}}\left(\mathrm{CeSiO}_{4}\right)=\Delta H_{13}=-\Delta H_{2}+\Delta H_{3}+\Delta H_{4}$

Standard enthalpy of formation of stetindite:

(14) $\Delta H_{\mathrm{f}}^{\circ}\left(\mathrm{CeSiO}_{4}\right)=\Delta H_{13}+\Delta H_{4}+\Delta H_{5}$

$\Delta H_{\mathrm{f}}^{\circ}=-1974.2 \pm 4.0$ 
379 Table 2 Enthalpy of formation from oxides for orthosilicate end-members, coming from 380 experiments and calculations at $25^{\circ} \mathrm{C}$.

\begin{tabular}{|c|c|c|c|c|}
\hline & $\begin{array}{c}\mathrm{CN} \mathrm{A}^{4+} \text { Ionic Radii } \\
(\AA)\end{array}$ & $\begin{array}{c}\Delta H_{\mathrm{f}}^{\circ} \mathrm{AO}_{2} \\
(\mathrm{~kJ} / \mathrm{mol})\end{array}$ & $\begin{array}{c}\Delta H_{\mathrm{f}}^{\circ} \mathrm{ASiO}_{4} \\
(\mathrm{~kJ} / \mathrm{mol})\end{array}$ & $\begin{array}{c}\Delta H_{\mathrm{f}, \mathrm{ox}, 25^{\circ} \mathrm{C}} \\
\mathrm{ASiO}_{4}(\mathrm{~kJ} / \mathrm{mol})\end{array}$ \\
\hline zircon & 0.83 & $-1100.6 \pm 1.7^{a}$ & $-2035.5 \pm 3.4^{\mathrm{a}}$ & $-24.2 \pm 2.8^{\mathrm{a}}$ \\
\hline hafnon & 0.84 & $-1117.6 \pm 1.6^{a}$ & $-2050.3 \pm 5.1^{\mathrm{a}}$ & $-22.3 \pm 4.7^{a}$ \\
\hline stetindite & 0.97 & $-1090.4 \pm 1.0^{b}$ & $-1971.9 \pm 3.6^{\mathrm{e}}$ & $27.5 \pm 3.1^{\mathrm{e}}$ \\
\hline thorite & 1.05 & $-1226.4 \pm 3.5^{b}$ & $-2143.5 \pm 6.8^{c}$ & $-6.4 \pm 5.7^{\mathrm{c}}$ \\
\hline $\mathrm{PaSiO}_{4}$ & 1.01 & $-1107.0 \pm 15.0^{b}$ & $-2003.6 \pm 15.1^{f}$ & $14.1 \pm 2.9^{f}$ \\
\hline coffinite & 1.00 & $-1085.0 \pm 1.0^{b}$ & $-1970.0 \pm 4.2^{\mathrm{d}}$ & $25.6 \pm 3.9^{\mathrm{d}}$ \\
\hline $\mathrm{NpSiO}_{4}$ & 0.98 & $-1078.5 \pm 2.7^{b}$ & $-1961.7 \pm 4.1^{f}$ & $27.5 \pm 5.7^{f}$ \\
\hline $\mathrm{PuSiO}_{4}$ & 0.96 & $-1055.8 \pm 1.0^{\mathrm{b}}$ & $-1930.1 \pm 4.1^{\mathrm{f}}$ & $36.4 \pm 7.6^{\mathrm{f}}$ \\
\hline $\mathrm{AmSiO}_{4}$ & 0.95 & $-932.2 \pm 3.0^{\mathrm{b}}$ & $-1802.0 \pm 5.3^{f}$ & $40.9 \pm 8.5^{\mathrm{f}}$ \\
\hline $\mathrm{CmSiO}_{4}$ & 0.95 & Not Available & Not Available & $40.9 \pm 8.5^{\mathrm{f}}$ \\
\hline $\mathrm{BkSiO}_{4}$ & 0.93 & Not Available & Not Available & $49.8 \pm 10.4^{\mathrm{f}}$ \\
\hline $\mathrm{CfSiO}_{4}$ & 0.92 & Not Available & Not Available & $54.3 \pm 11.3^{\mathrm{f}}$ \\
\hline
\end{tabular}
$(2015)^{48}$; e. Experimentally derived in this study; ${ }^{\text {f. }}$ Calculated in this study. 


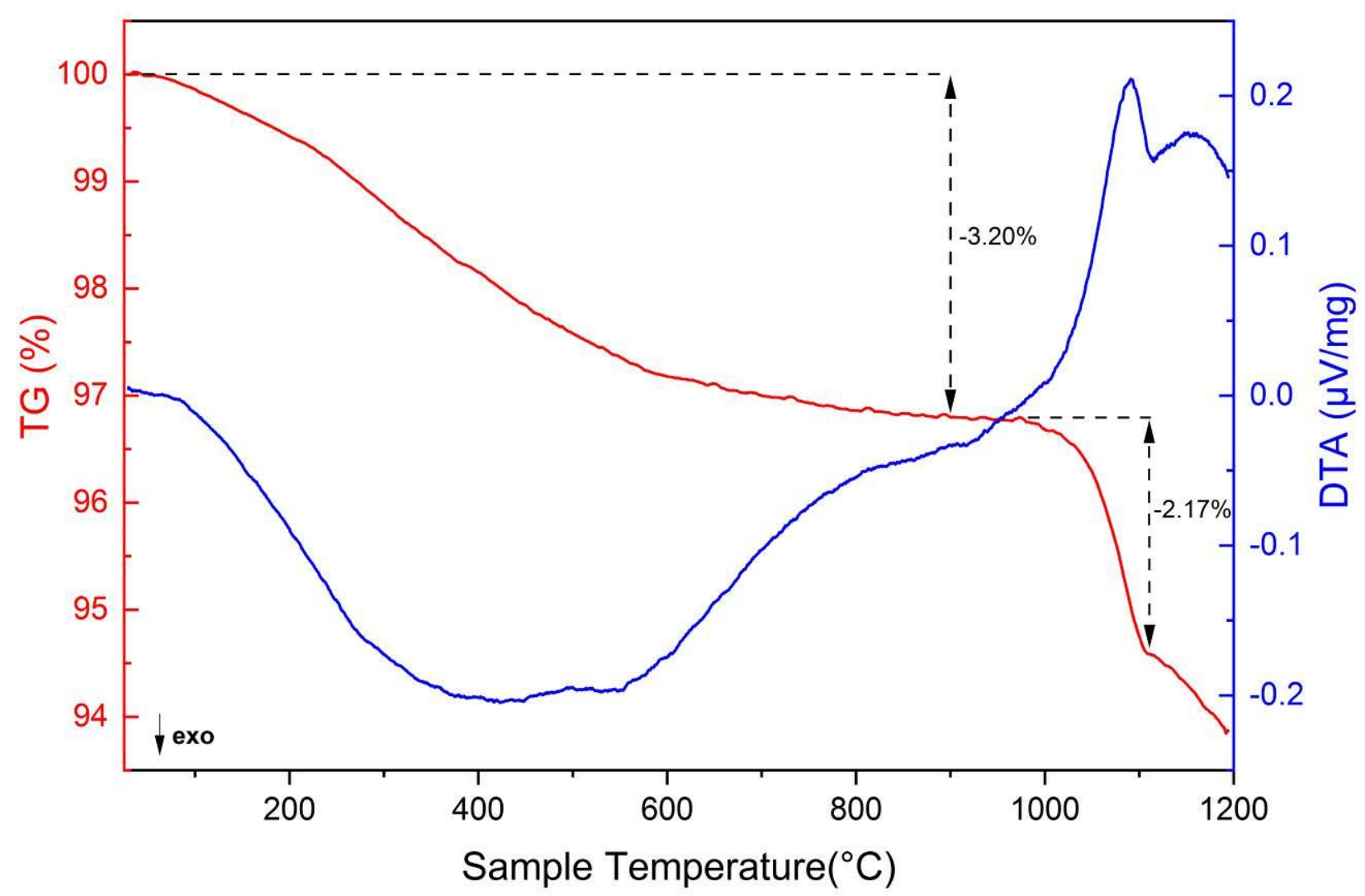

384

385 Figure 1. TGA-DTA curve obtained from $\mathrm{CeSiO}_{4} \cdot 0.43 \mathrm{H}_{2} \mathrm{O}$ (sample mass: $4.5220 \pm 0.0005 \mathrm{mg}$ ) 386 when heating up to $1200^{\circ} \mathrm{C}$ under $\mathrm{N}_{2}$ atmosphere. 


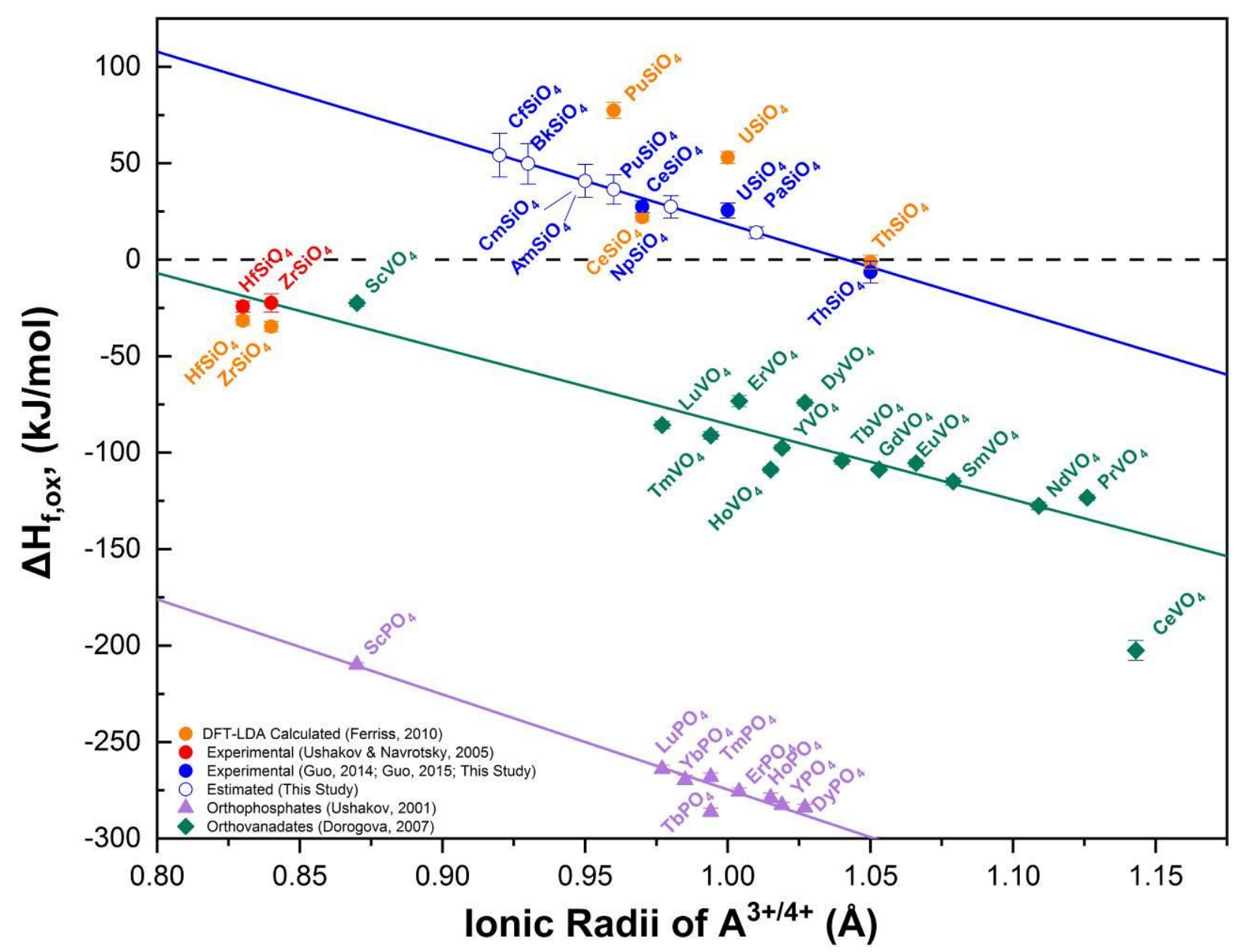

Figure 2. Enthalpy of formation from binary oxides obtained for orthosilicates $\left(\mathrm{ASiO}_{4}\right)$, orthovanadates $\left(\mathrm{AVO}_{4}\right)$, and orthophosphates $\left(\mathrm{APO}_{4}\right)$ that crystallize with the zircon structure $\left(\mathrm{I} 4_{1} / \mathrm{amd}\right)$ as a function of ionic radius of a metal cation $\left(\mathrm{A}^{4+}\right.$ or $\left.\mathrm{A}^{3+}\right)$ in the eightfold coordination. Data shown as filled blue circles were used in order to estimate the values for the empty blue circles by means of linear regression. The equation which describes the blue line is $\Delta H_{\mathrm{f}, \text { ox }}=(-$ $446.3 \pm 152.5) r-(464.9 \pm 153.6)$, with an adjusted $R^{2}=0.79096$. Data denoted with orange circles was derived by utilizing the DFT-LDA results for the enthalpy of formation of orthosilicate materials at $-273^{\circ} \mathrm{C}$ reported by Ferriss et $a l .^{37}$, in conjunction with the standard enthalpy of formation of quartz ${ }^{117}$ and $\mathrm{AO}_{2}{ }^{105}(\mathrm{~A}=\mathrm{Ce}, \mathrm{U}, \mathrm{Th}, \mathrm{Pu})$. This assumes that the energetic contributions from the respective heat capacities are negligible to the overall calculation, so the enthalpy of formation data reported by Ferriss et al. can be treated as approximately equal to standard state conditions. Data points as purple triangles and green diamonds are for orthophosphates $^{59}$ and orthovanadates ${ }^{106}$, respectively. 


\section{References:}

(1) Burns, P. C.; Ewing, R. C.; Navrotsky, A. Nuclear Fuel in a Reactor Accident. Science (80-. ). 2012, 335 (6073), 1184-1188. https://doi.org/10.1126/science.1211285.

(2) Orlova, A. I.; Ojovan, M. I. Ceramic Mineral Waste-Forms for Nuclear Waste Immobilization. Materials (Basel). 2019, 12 (16), 2638. https://doi.org/10.3390/ma12162638.

(3) Goel, A.; McCloy, J. S.; Pokorny, R.; Kruger, A. A. Challenges with Vitrification of Hanford High-Level Waste (HLW) to Borosilicate Glass - An Overview. J. Non-Crystalline Solids X. 2019, 4 (August), 1-19. https://doi.org/10.1016/j.nocx.2019.100033.

(4) Wegel, S.; Czempinski, V.; Oei, P.-Y.; Wealer, B. Transporting and Storing High-Level Nuclear Waste in the U.S.-Insights from a Mathematical Model. Appl. Sci. 2019, 9 (12). https://doi.org/10.3390/app9122437.

(5) Weber, W. J.; Navrotsky, A.; Stefanovsky, S.; Vance, E. R.; Vernaz, E. Materials Science of High-Level Immobilization. MRS Bull. 2009, 34 (January 2009). https://doi.org/https://doi.org/10.1557/mrs2009.12.

(6) Ewing, R. C. Long-Term Storage of Spent Nuclear Fuel. Nat. Mater. 2015, 14 (3), 252-257. https://doi.org/10.1038/nmat4226.

(7) Guo, X.; Navrotsky, A.; Kukkadapu, R. K.; Engelhard, M. H.; Lanzirotti, A.; Newville, M.; Ilton, E. S.; Sutton, S. R.; Xu, H. Structure and Thermodynamics of Uranium-Containing Iron Garnets. Geochim. Cosmochim. Acta. 2016, 189, 269-281. https://doi.org/10.1016/j.gca.2016.05.043.

(8) Guo, X.; Szenknect, S.; Mesbah, A.; Clavier, N.; Poinssot, C.; Wu, D.; Xu, H.; Dacheux, N.; Ewing, R. C.; Navrotsky, A. Energetics of a Uranothorite $\left(\mathrm{Th}_{1-\mathrm{x}} \mathrm{U}_{\mathrm{x}} \mathrm{SiO}_{4}\right)$ Solid Solution. Chem. Mater. 2016, 28 (19), 7117-7124. https://doi.org/10.1021/acs.chemmater.6b03346.

(9) Guo, X.; Tavakoli, A. H.; Sutton, S.; Kukkadapu, R. K.; Qi, L.; Lanzirotti, A.; Newville, M.; Asta, M.; Navrotsky, A. Cerium Substitution in Yttrium Iron Garnet: Valence State, Structure, and Energetics. Chem. Mater. 2014, 26 (2), 1133-1143. https://doi.org/10.1021/cm403444f.

(10) Chung, C. K.; O’Quinn, E. C.; Neuefeind, J. C.; Fuentes, A. F.; Xu, H.; Lang, M.; Navrotsky, A. Thermodynamic and Structural Evolution of Mechanically Milled and Swift Heavy Ion Irradiated $\mathrm{Er}_{2} \mathrm{Ti}_{2} \mathrm{O}_{7} \quad$ Pyrochlore. Acta Mater. 2019, 181, 309-317. https://doi.org/10.1016/j.actamat.2019.09.022.

(11) Helean, K. B.; Navrotsky, A.; Vance, E. R.; Carter, M. L.; Ebbinghaus, B.; Krikorian, O.; Lian, J.; Wang, L. M.; Catalano, J. G. Enthalpies of Formation of Ce-Pyrochlore, $\mathrm{Ca}_{0.93} \mathrm{Ce}_{1.00} \mathrm{Ti}_{2.035} \mathrm{O}_{7.00}$, U-Pyrochlore, $\mathrm{Ca}_{1.46} \mathrm{U}^{4+}{ }_{0.23} \mathrm{U}^{6+}{ }_{0.46} \mathrm{Ti}_{1.85} \mathrm{O}_{7.00}$ and Gd-Pyrochlore, $\mathrm{Gd}_{2} \mathrm{Ti}_{2} \mathrm{O}_{7}$ : Three Materials Relevant to the Proposed Waste Form for Excess Weapons Plutonium. J. Nucl. Mater. 2002, 303 (2-3), 226-239. https://doi.org/10.1016/s0022-3115(02)00795-x.

(12) Neumeier, S.; Kegler, P.; Arinicheva, Y.; Shelyug, A.; Kowalski, P. M.; Schreinemachers, C.; Navrotsky, A.; Bosbach, D. Thermochemistry of $\mathrm{La}_{1-\mathrm{x}} \mathrm{Ln}_{\mathrm{x}} \mathrm{PO}_{4}$-Monazites $(\mathrm{Ln}=\mathrm{Gd}, \mathrm{Eu}) . J$. Chem. Thermodyn. 2017, 105, 396-403. https://doi.org/10.1016/j.jct.2016.11.003.

(13) Ewing, R. C.; Lutze, W.; Weber, W. J. Zircon: A Host-Phase for the Disposal of Weapons Plutonium. J. Mater. Res. 1995, 10 (2), 243-246. https://doi.org/10.1557/JMR.1995.0243.

(14) Ewing, R. C. Nuclear Waste Forms for Actinides. Proc. Natl. Acad. Sci. U. S. A. 1999, 96 (7), 3432-3439. https://doi.org/10.1073/pnas.96.7.3432.

(15) Ushakov, S. V.; Gong, W.; Yagokina, M. M.; Helean, K. B.; Lutze, W.; Ewing, R. C. Solid Solutions of Ce, U, and Th in Zircon. Ceram. Trans. 1999, 93, 357-363.

(16) White, W. M. Isotope Geochemistry, 1st ed.; John Wiley \& Sons, 2015.

(17) Finch, R. J.; Hanchar, J. M. Structure and Chemistry of Zircon and Zircon-Group Minerals. Rev. Mineral. Geochemistry 2003, 53 (1), 1-26. 
449

450

451

452

453

454

455

456

457

458

459

460

461

462

463

464

465

466

467

468

469

470

471

472

473

474

475

476

477

478

479

480

481

482

483

484

485

486

487

488

489

490

491

492

493

494

(18) McCarthy, G. J.; White, W. B.; Pfoertsch, D. E. Synthesis of Nuclear Waste Monazites, Ideal Actinide Hosts for Geologic Disposal. Mater. Res. Bull. 1978, 13 (11), 1239-1245. https://doi.org/10.1016/0025-5408(78)90215-5.

(19) Ewing, R. C. The Design and Evaluation of Nuclear-Waste Forms: Clues from Mineralogy. Can. Mineral. 2001, 39 (3), 697-715. https://doi.org/10.2113/gscanmin.39.3.697.

(20) Lutze, W.; Ewing, R. C. Radioactive Waste Forms for the Future; North-Holland Physics Publishing: Amsterdam, 1988.

(21) Ewing, R. C.; Weber, W. J. Actinide Waste Forms and Radiation Effects. In The Chemistry of the Actinide and Transactinide Elements; Morss, L. R., Edelstein, N. M., Fuger, J., Eds.; Springer: Dordrecht, 2010; Vol. 3813, pp 3813-3887. https://doi.org/10.1007/978-94-007-0211$0 \_35$.

(22) Weber, W. J.; Ewing, R. C. Chapter 10: Ceramic Waste Forms for Uranium and Transuranium Elements. In Uranium: Cradle to Grave; Burns, P. C., Sigmon, G. E., Eds.; Mineralogical Association of Canada, 2013; pp 317-336.

(23) Weber, W. J.; Ewing, R. C.; Vance, E. R.; Gregg, D.; Peuget, S.; Wiss, T. Plutonium in Waste Forms. In Plutonium Handbook; Clark, D. L., Geeson, D. A., Hanrahan Jr., R. J., Eds.; American Nuclear Society, 2019; pp 2349-2422.

(24) Ewing, R. C.; Weber, W. J.; Clinard, F. W. Radiation Effects in Nuclear Waste Forms for High-Level Radioactive Waste. Prog. Nucl. Energy 1995, 29 (2), 63-127. https://doi.org/10.1016/0149-1970(94)00016-Y.

(25) Weber, W. J.; Ewing, R. C.; Lutze, W. Performance Assessment of Zircon as a Waste Form for Excess Weapons Plutonium Under Deep Borehole Burial Conditions. Mater. Res. Soc. Symp. Proc. 1996, 412, 25-32. https://doi.org/https://doi.org/10.1557/PROC-412-25.

(26) McMurdie, H. F.; Hall, F. P. Phase Diagrams for Ceramists: Supplement No. 1. J. Am. Ceram. Society. 1947, No. 1, 154-164.

(27) Grover, V.; Tyagi, A. K. Preparation and Bulk Thermal Expansion Studies in $\mathrm{M}_{1-\mathrm{X}} \mathrm{Ce}_{\mathrm{X}} \mathrm{SiO}_{4}$ $(\mathrm{M}=\mathrm{Th}, \mathrm{Zr})$ System, and Stabilization of Tetragonal $\mathrm{ThSiO}_{4}$. J. Alloys Comps. 2005, 390 (1-2), 112-114. https://doi.org/10.1016/j.jallcom.2004.05.091.

(28) Subbarao, E. C.; Agrawal, D. K.; McKinstry, H. A.; Sallese, C. W.; Roy, R. Thermal Expansion of Compounds of Zircon Structure. J. Am. Ceram. Soc. 1990, 73 (5), 1246-1252. https://doi.org/10.1111/j.1151-2916.1990.tb05187.x.

(29) Nesse, W. D. Introduction to Mineralogy, 2nd ed.; Oxford University Press, 2000.

(30) Poirot, I. S.; Kot, W. K.; Edelstein, N. M.; Abraham, M. M.; Finch, C. B.; Boatner, L. A. Optical Study and Analysis of Pu4+ in Single Crystals of $\mathrm{ZrSiO}_{4}$. Phys. Rev. B 1989, 39 (10), 6388-6394. https://doi.org/10.1103/PhysRevB.39.6388.

(31) Weber, W. J. Radiation-Induced Defects and Amorphization in Zircon. J. Mater. Res. 1990, 5 (11), 2687-2697. https://doi.org/10.1557/JMR.1990.2687.

(32) Weber, W. J. Alpha-Decay-Induced Amorphization in Complex Silicate Structures. J. Am. Ceram. Soc. 1993, 76 (7), 1729-1738. https://doi.org/10.1111/j.1151-2916.1993.tb06641.x.

(33) Anderson, E. B.; Burakov, B. E.; Pazukhin, E. M. High-Uranium Zircon from "Chernobyl Lavas." Radiochim. Acta 1992, 60 (2-3), 149-152. https://doi.org/10.1524/ract.1993.60.23.149.

(34) Keller, V. C. Untersuchungen Über Die Germanate Und Silikate Des Typs $\mathrm{ABO}_{4}$ Der Vierwertigen Elemente Thorium Bis Americium. Nukleonik 1963, No. 5, 41-48.

(35) Estevenon, P.; Welcomme, E.; Tamain, C.; Jouan, G.; Szenknect, S.; Mesbah, A.; Poinssot, C.; Moisy, P.; Dacheux, N. Formation of $\mathrm{PuSiO}_{4}$ under Hydrothermal Conditions. Dalt. Trans. 2020. https://doi.org/https://doi.org/10.1039/D0DT01183E. 
(36) Hanchar, J. M.; Burakov, B. E.; Zamoryanskaya, M. V.; Garbuzov, V. M.; Kitsay, A. A.; Zirlin, V. A. Investigation of Pu Incorporation into Zircon Single Crystal. Mater. Res. Soc. Symp. Proc. 2004, 824, 225-229. https://doi.org/10.1557/proc-824-cc4.2.

(37) Ferriss, E. D. A.; Ewing, R. C.; Becker, U. Simulation of Thermodynamic Mixing Properties of Actinide-Containing Zircon Solid Solutions. Am. Mineral. 2010, 95 (2-3), 229-241. https://doi.org/10.2138/am.2010.3318.

(38) Zamoryanskaya, M. V.; Burakov, B. E. Feasibility Limits in Using Cerium as a Surrogate for Plutonium Incorporation in Zircon, Zirconia and Pyrochlore. Mater. Res. Soc. Symp. - Proc. 2001, 663, 301-306. https://doi.org/10.1557/proc-663-301.

(39) Putnam, R. L.; Navrotsky, A.; Cordfunke, E. H. P.; Huntelaar, M. E. Thermodynamics of Formation of Two Cerium Aluminum Oxides, $\mathrm{CeAlO}_{3(\mathrm{~s})}$ And $\mathrm{CeAl}_{12} \mathrm{O}_{19.918(\mathrm{~s})}$, and Cerium Sesquioxide, $\mathrm{Ce}_{2} \mathrm{O}_{3(\mathrm{~s})}$ At $\mathrm{T}=298.15$ K. J. Chem. Thermodyn. 2000, 32 (7), 911-921. https://doi.org/10.1006/jcht.2000.0665.

(40) Putnam, R. L.; Gallegos, U. F.; Ebbinghaus, B. B.; Navrotsky, A.; Helean, K. B.; Ushakov, S. V; Woodfield, B. F.; Boerio-Goates, J.; Williamson, M. A. Formation Energetics of Ceramic Phases Related to Surplus Plutonium Disposition. Ceram. Trans. 2001, 119(Enviro, 147-158.

(41) Marra, J. C.; Cozzi, A. D.; Pierce, R. A.; Pareizs, J. M.; Jurgensen, A. R.; Missimer, D. M. Cerium as a Surrogate in the Plutonium Immobilized Form. In Environmental Issues and Waste Management Technologies in the Ceramic and Nuclear Industries; Smith, G. L., Sundaram, S. K., Spearing, D. R., Eds.; American Ceramic Society, 2002; pp 381-388.

(42) Shannon, R. D. Revised Effective Ionic Radii and Systematic Studies of Interatomic Distances in Halides and Chalcogenides. Acta Crystallogr. Sect. A 1976, 32 (5), 751-766. https://doi.org/10.1107/S0567739476001563.

(43) Estevenon, P.; Welcomme, E.; Szenknect, S.; Mesbah, A.; Moisy, P.; Poinssot, C.; Dacheux, N. Preparation of $\mathrm{CeSiO}_{4}$ from Aqueous Precursors under Soft Hydrothermal Conditions. Dalt. Trans. 2019, 48 (22), 7551-7559. https://doi.org/10.1039/c9dt01258c.

(44) Estevenon, P.; Kaczmarek, T.; Vadot, F.; Dumas, T.; Solari, P. L.; Welcomme, E.; Szenknect, S.; Mesbah, A.; Moisy, P.; Poinssot, C.; Dacheaux, N. Formation of $\mathrm{CeSiO}_{4}$ from Cerium (III) Silicate Precursors. Dalt. Trans. 2019, 48, 10455-10463. https://doi.org/10.1039/c9dt01990a.

(45) Sverjensky, D. A.; Molling, P. A. A Linear Free Energy Relationship for Crystalline Solids and Aqueous Ions. Nature 1992, 356 (6366), 231-234. https://doi.org/10.1038/356231a0.

(46) Navrotsky, A. Systematic Trends and Prediction of Enthalpies of Formation of Refractory Lanthanide and Actinide Ternary Oxide Phases. Ceram. Trans. 2001, No. 119, 137-146.

(47) Helean, K. B.; Navrotsky, A.; Lumpkin, G. R.; Colella, M.; Lian, J.; Ewing, R. C.; Ebbinghaus, B.; Catalano, J. G. Enthalpies of Formation of U-, Th-, Ce-Brannerite: Implications for Plutonium Immobilization. J. Nucl. Mater. 2003, 320 (3), 231-244. https://doi.org/10.1016/S0022-3115(03)00186-7.

(48) Guo, X.; Szenknect, S.; Mesbah, A.; Labs, S.; Clavier, N.; Poinssot, C.; Ushakov, S. V.; Curtius, H.; Bosbach, D.; Ewing, R. C.; Burns, P.C.; Dacheux, N; Navrotsky, A. Thermodynamics of Formation of Coffinite, $\mathrm{USiO}_{4}$. Proc. Natl. Acad. Sci. 2015, 112 (21), 65516555. https://doi.org/10.1073/pnas.1507441112.

(49) Szenknect, S.; Mesbah, A.; Cordara, T.; Clavier, N.; Brau, H. P.; Le Goff, X.; Poinssot, C.; Ewing, R. C.; Dacheux, N. First Experimental Determination of the Solubility Constant of Coffinite. Geochim. Cosmochim. Acta 2016, 181, 36-53. https://doi.org/10.1016/j.gca.2016.02.010. 
541

542

543

544

545

546

547

548

549

550

551

552

553

554

555

556

557

558

559

560

561

562

563

564

565

566

567

568

569

570

571

572

573

574

575

576

577

578

579

580

581

582

583

584

585

586

587

588

(50) Costin, D. T.; Mesbah, A.; Clavier, N.; Dacheux, N.; Poinssot, C.; Szenknect, S.; Ravaux, J. How to Explain the Difficulties in the Coffinite Synthesis from the Study of Uranothorite? Inorg. Chem. 2011, 50 (21), 11117-11126. https://doi.org/10.1021/ic2016758.

(51) Frondel, C.; Collette, R. L. Hydrothermal Synthesis of Zircon, Thorite and Huttonite. Am. Mineral. 1957, 42 (378), 759-765.

(52) Mumpton, F. A.; Roy, R. Hydrothermal Stability Studies of the Zircon-Thorite Group. Geochim. Cosmochim. Acta 1961, 21 (3-4), 217-238. https://doi.org/10.1016/s00167037(61)80056-2.

(53) Estevenon, P.; Welcomme, E.; Szenknect, S.; Mesbah, A.; Moisy, P.; Poinssot, C.; Dacheux, $\mathrm{N}$. Impact of Carbonate Ions on the Synthesis of $\mathrm{ThSiO}_{4}$ under Hydrothermal Conditions. Inorg. Chem. 2018, 57 (19), 12398-12408. https://doi.org/10.1021/acs.inorgchem.8b02146.

(54) Estevenon, P.; Welcomme, E.; Szenknect, S.; Mesbah, A.; Moisy, P.; Poinssot, C.; Dacheux, N. Multiparametric Study of the Synthesis of $\mathrm{ThSiO}_{4}$ under Hydrothermal Conditions. Inorg. Chem. 2018, 57 (15), 9393-9402. https://doi.org/10.1021/acs.inorgchem.8b01390.

(55) Schlüter, J.; Malcherek, T.; Husdal, T. A. The New Mineral Stetindite, $\mathrm{CeSiO}_{4}$, a Cerium End-Member of the Zircon Group. Neues Jahrb. fur Mineral. Abhandlungen 2009, 186 (2), 195200. https://doi.org/10.1127/0077-7757/2009/0146.

(56) Navrotsky, A.; Kleppa, O. J. A Calorimetric Study of Molten Na2MoO4-MoO3 Mixtures at 970 K. Inorg. Chem. 1967, 6 (11), 2119-2121. https://doi.org/10.1021/ic50057a047.

(57) Navrotsky, A. Progress and New Directions in High Temperature Calorimetry. Phys. Chem. Miner. 1977, 2 (December), 89-104.

(58) Navrotsky, A. Progress and New Directions in Calorimetry: A 2014 Perspective. J. Am. Ceram. Soc. 2014, 97 (11), 3349-3359. https://doi.org/10.1111/jace.13278.

(59) Ushakov, S. V.; Helean, K. B.; Navrotsky, A.; Boatner, L. A. Thermochemistry of Rare-Earth Orthophosphates. J. Mater. Res. 2001, $16 \quad$ (9), 2623-2633. https://doi.org/10.1557/JMR.2001.0361.

(60) Helean, K. B.; Navrotsky, A. Oxide Melt Solution Calorimetry of Rare Earth Oxides. Techniques, Problems, Cross-Checks, Successes. J. Therm. Anal. Calorim. 2002, 69 (3), 751-771. https://doi.org/10.1023/A:1020687418374.

(61) Guo, X.; Boukhalfa, H.; Mitchell, J. N.; Ramos, M.; Gaunt, A. J.; Migliori, A.; Roback, R. C.; Navrotsky, A.; Xu, H. Sample Seal-and-Drop Device and Methodology for High Temperature Oxide Melt Solution Calorimetric Measurements of $\mathrm{PuO}_{2}$. Rev. Sci. Instrum. 2019, 90 (4), 044101. https://doi.org/10.1063/1.5093567

(62) Gorman-Lewis, D.; Mazeina, L.; Fein, J. B.; Szymanowski, J. E. S.; Burns, P. C.; Navrotsky, A. Thermodynamic Properties of Soddyite from Solubility and Calorimetry Measurements. J. Chem. Thermodyn. 2007, 39 (4), 568-575. https://doi.org/10.1016/j.jct.2006.09.005.

(63) Navrotsky, A.; Shvareva, T.; Guo, X. Thermodynamics of Uranium Minerals and Related Materials. In Mineralogical Association of Canada Short Course 43; 2013; pp 1-18.

(64) Guo, X.; Tiferet, E.; Qi, L.; Solomon, J. M.; Lanzirotti, A.; Newville, M.; Engelhard, M. H.; Kukkadapu, R. K.; Wu, D.; Ilton, E. S.; Asta, M.; Sutton, S.R.; Xu, H.; Navrotsky, A. U(v) in Metal Uranates: A Combined Experimental and Theoretical Study of $\mathrm{MgUO}_{4}, \mathrm{CrUO}_{4}$, and $\mathrm{FeUO}_{4}$. Dalt. Trans. 2016, 45 (11), 4622-4632. https://doi.org/10.1039/c6dt00066e.

(65) Guo, X.; Wu, D.; Xu, H.; Burns, P. C.; Navrotsky, A. Thermodynamic Studies of Studtite Thermal Decomposition Pathways via Amorphous Intermediates $\mathrm{UO}_{3}, \mathrm{U}_{2} \mathrm{O}_{7}$, and $\mathrm{UO}_{4}$. J. Nucl. Mater. 2016, 478, 158-163. https://doi.org/10.1016/j.jnucmat.2016.06.014.

(66) Clavier, N.; Szenknect, S.; Costin, D. T.; Mesbah, A.; Poinssot, C.; Dacheux, N. From Thorite to Coffinite: A Spectroscopic Study of $\mathrm{Th}_{1-\mathrm{x}} \mathrm{U}_{\mathrm{x}} \mathrm{SiO}_{4}$ Solid Solutions. Spectrochim. Acta Part A Mol. Biomol. Spectrosc. 2014, 118, 302-307. https://doi.org/10.1016/j.saa.2013.08.093. 
602

603

604

605

606

607

608

609

610

611

612

613

614

615

616

617

618

619

620

621

622

623

624

625

626

627

628

629

630

631

632

633

634

635

(67) Speer, J. A.; Cooper, B. J. Crystal Structure of Synthetic Hafnon, $\mathrm{HfSiO}_{4}$, Comparison with Zircon and the Actinide Orthosilicates. Am. Mineral. 1982, 67 (7-8), 804-808.

(68) Janeczek, J.; Ewing, R. C. Coffinitization - A Mechanism for the Alteration of $\mathrm{UO}_{2}$ under Reducing Conditions. Mater. Res. Soc. Symp. Proc. 1992, 257. https://doi.org/10.1017/CBO9781107415324.004.

(69) Finch, R.; Murakami, T. Systematics and Paragenesis of Uranium Minerals. In Uranium: Mineralogy, Geochemistry, and the Environment; Burns, P. C., Finch, R. J., Eds.; 1999; pp 91179. https://doi.org/10.1515/9781501509193-008.

(70) Janeczek, J. Composition and Origin of Coffinite from Jachymov, Czechoslovakia. Neues Jahrb. für Mineral. Monatshefte 1991, 9, 385-395.

(71) Nasdala, L.; Beran, A.; Libowitzky, E.; Wolf, D. The Incorporation of Hydroxyl Groups and Molecular Water in Natural Zircon $\left(\mathrm{ZrSiO}_{4}\right)$. Am. J. Sci. 2001, 301 (10), 831-857. https://doi.org/10.2475/ajs.301.10.831.

(72) Miller, F. A.; Wilkins, C. H. Infrared Spectra and Characteristic Frequencies of Inorganic Ions. Anal. Chem. 1952, 24 (8), 1253-1294. https://doi.org/10.1021/ac60068a007.

(73) Speer, J. A. Zircon. In Reviews in Mineralogy and Geochemistry; 1982; Vol. 5, pp 66-112.

(74) Labs, S.; Hennig, C.; Weiss, S.; Curtius, H.; Zänker, H.; Bosbach, D. Synthesis of Coffinite, $\mathrm{USiO}_{4}$, and Structural Investigations of $\mathrm{U}_{\mathrm{x}} \mathrm{Th}_{(1-\mathrm{x})} \mathrm{SiO}_{4}$ Solid Solutions. Environ. Sci. Technol. 2014, 48 (1), 854-860. https://doi.org/10.1021/es403995b.

(75) Hirono, T.; Tanikawa, W. Implications of the Thermal Properties and Kinetic Parameters of Dehydroxylation of Mica Minerals for Fault Weakening, Frictional Heating, and Earthquake Energetics. Earth Planet. Sci. Lett. 2011, $307 \quad$ (1-2), 161-172. https://doi.org/10.1016/j.epsl.2011.04.042.

(76) Perrillat, J. P.; Daniel, I.; Koga, K. T.; Reynard, B.; Cardon, H.; Crichton, W. A. Kinetics of Antigorite Dehydration: A Real-Time X-Ray Diffraction Study. Earth Planet. Sci. Lett. 2005, 236 (3-4), 899-913. https://doi.org/10.1016/j.epsl.2005.06.006.

(77) Tavakoli, A. H.; Maram, P. S.; Widgeon, S. J.; Rufner, J.; Van Benthem, K.; Ushakov, S.; Sen, S.; Navrotsky, A. Amorphous Alumina Nanoparticles: Structure, Surface Energy, and Thermodynamic Phase Stability. J. Phys. Chem. C 2013, 117 (33), 17123-17130. https://doi.org/10.1021/jp405820g.

(78) Levchenko, A. A.; Li, G.; Boerio-Goates, J.; Woodfield, B. F.; Navrotsky, A. TiO 2 Stability Landscape: Polymorphism, Surface Energy, and Bound Water Energetics. Chem. Mater. 2006, 18 (26), 6324-6332. https://doi.org/10.1021/cm061183c.

(79) Ushakov, S. V.; Navrotsky, A. Direct Measurements of Water Adsorption Enthalpy on Hafnia and Zirconia. Appl. Phys. Lett. 2005, 87 (16), 1-3. https://doi.org/10.1063/1.2108113.

(80) Chen, F.; Ewing, R. C.; Clark, S. B. The Gibbs Free Energies and Enthalpies of Formation of $\mathrm{U}^{6+}$ Phases: An Empirical Method of Prediction. Am. Mineral. 1999, 84 (4), 650-664. https://doi.org/10.2138/am-1999-0418.

(81) $\mathrm{Xu}, \mathrm{H}$.; Wang, Y.; Barton, L. L. Application of a Linear Free Energy Relationship to Crystalline Solids of $\mathrm{MO}_{2}$ and $\mathrm{M}(\mathrm{OH})_{4}$. J. Nucl. Mater. 1999, 273 (3), 343-346. https://doi.org/10.1016/S0022-3115(99)00092-6.

(82) Xu, H.; Wang, Y. Use of Linear Free Energy Relationship to Predict Gibbs Free Energies of Formation of Pyrochlore Phases $\left(\mathrm{CaMTi}_{2} \mathrm{O}_{7}\right)$. J. Nucl. Mater. 1999, 275 (2), 216-220. https://doi.org/10.1016/S0022-3115(99)00189-0.

(83) Navrotsky, A. Thermochemical Insights into Refractory Ceramic Materials Based on Oxides with Large Tetravalent Cations. J. Mater. Chem. 2005, 15 (19), 1883-1890. https://doi.org/10.1039/b417143h. 
650

651

652

653

654

655

656

657

658

659

660

661

662

663

664

665

666

667

668

669

670

671

672

673

674

675

676

677

678

679

680

681

682

(84) Qi, J.; Guo, X.; Mielewczyk-Gryn, A.; Navrotsky, A. Formation Enthalpies of $\mathrm{LaLnO}_{3}$ (Ln=Ho, Er, Tm and Yb) Interlanthanide Perovskites. J. Solid State Chem. 2015, 227, 150-154. https://doi.org/10.1016/j.jssc.2015.03.026.

(85) Helean, K. B.; Ushakov, S. V.; Brown, C. E.; Navrotsky, A.; Lian, J.; Ewing, R. C.; Farmer, J. M.; Boatner, L. A. Formation Enthalpies of Rare Earth Titanate Pyrochlores. J. Solid State Chem. 2004, 177 (6), 1858-1866. https://doi.org/10.1016/j.jssc.2004.01.009.

(86) Cotton, S. Lanthanide and Actinide Chemistry; John Wiley \& Sons, Ltd, 2006.

(87) Seaborg, G. T. The Transuranium Elements. Nature 1946, 104 (2704), 379-386. https://doi.org/10.1038/159863a0.

(88) Seaborg, G. T. Origin of the Actinide Concept. In Handbook on the Physics and Chemistry of Rare Earths; Gschneidner, K. A., Eyring, L. J., Choppin, G. R., Lander, G. H., Eds.; Elsevier B.V, 1994; Vol. 18, pp 1-26. https://doi.org/https://doi.org/10.1016/S0168-1273(05)80041-8.

(89) Silver, M. A.; Albrecht-Schmitt, T. E. Evaluation of F-Element Borate Chemistry. Coord. Chem. Rev. 2016, 323, 36-51. https://doi.org/10.1016/j.ccr.2016.02.015.

(90) Albrecht-Schmitt, T. E. Organometallic and Coordination Chemistry of the Actinides; Springer, 2012. https://doi.org/10.1093/ntr/nts065.

(91) Horne, G. P.; Grimes, T. S.; Bauer, W. F.; Dares, C. J.; Pimblott, S. M.; Mezyk, S. P.; Mincher, B. J. Effect of Ionizing Radiation on the Redox Chemistry of Penta- And Hexavalent Americium. Inorg. Chem. 2019, 58 (13), 8551-8559. https://doi.org/10.1021/acs.inorgchem.9b00854.

(92) Sullivan, J. C.; Gordon, S.; Mulac, W. A.; Schmidt, K. H.; Cohen, D.; Sjoblom, R. Pulse Radiolysis Studies of Americium(III) and Curium(III) Ions in Perchlorate Media. The Preparation of Am II, Am IV, Cm II and Cm IV. Inorg. Nucl. Chem. Lett. 1976, 12 (8), 599-601.

(93) Keenan, T. K. Americium and Curium. J. Chem. Educ. 1959, 36 (1), 27-31. https://doi.org/10.1142/9781860943096_0004.

(94) White, F. D.; Dan, D.; Albrecht-Schmitt, T. E. Contemporary Chemistry of Berkelium and Californium. Chem. - A Eur. J. 2019, $25 \quad$ (44), 10251-10261. https://doi.org/10.1002/chem.201900586.

(95) Mincher, B. J.; Martin, L. R.; Schmitt, N. C. Diamylamylphosphonate Solvent Extraction of Am(VI) from Nuclear Fuel Raffinate Simulant Solution. Solvent Extr. Ion Exch. 2012, 30 (5), 445-456. https://doi.org/10.1080/07366299.2012.671108.

(96) Keenan, T. K. First Observation of Aqueous Tetravalent Curium. J. Am. Chem. Soc. 1961, 83 (17), 3719-3720. https://doi.org/10.1021/ja01478a039.

(97) Guo, X.; Xu, H. Enthalpies of Formation of Polyhalite: A Mineral Relevant to Salt Repository. J. Chem. Thermodyn. 2017, 114, 44-47. https://doi.org/10.1016/j.jct.2017.05.031.

(98) Xu, H.; Guo, X.; Bai, J. Thermal Behavior of Polyhalite: A High-Temperature Synchrotron XRD Study. Phys. Chem. Miner. 2017, 44 (2), 125-135. https://doi.org/10.1007/s00269-0160842-5.

(99) Timofeev, A.; Migdisov, A. A.; Williams-Jones, A. E.; Roback, R.; Nelson, A. T.; Xu, H. Uranium Transport in Acidic Brines under Reducing Conditions. Nat. Commun. 2018, 9 (1), $2-8$. https://doi.org/10.1038/s41467-018-03564-7.

(100) Fox, P. M.; Tinnacher, R. M.; Cheshire, M. C.; Caporuscio, F.; Carrero, S.; Nico, P. S. Effects of Bentonite Heating on U(VI) Adsorption. Appl. Geochemistry 2019, 109 (July). https://doi.org/10.1016/j.apgeochem.2019.104392.

(101) Utsunomiya, S.; Kersting, A. B.; Ewing, R. C. Groundwater Nanoparticles in the Far-Field at the Nevada Test Site: Mechanism for Radionuclide Transport. Environ. Sci. Technol. 2009, 43 (5), 1293-1298. https://doi.org/10.1021/es802181t. 
(102) Novikov, A. P.; Kalmykov, S. N.; Utsunomiya, S.; Ewing, R. C.; Horreard, F.; Merkulov, A.; Clark, S. B.; Tkachev, V. V.; Myasoedov, B. F. Colloid Transport of Plutonium in the FarField of the Mayak Production Association, Russia. Science (80-. ). 2006, 314 (5799), 638-641. https://doi.org/10.1126/science.1131307.

(103) Dittrich, T. M.; Boukhalfa, H.; Ware, S. D.; Reimus, P. W. Laboratory Investigation of the Role of Desorption Kinetics on Americium Transport Associated with Bentonite Colloids. J. Environ. Radioact. 2015, 148, 170-182. https://doi.org/10.1016/j.jenvrad.2015.07.001.

(104) Mesbah, A.; Szenknect, S.; Clavier, N.; Lozano-Rodriguez, J.; Poinssot, C.; Den Auwer, C.; Ewing, R. C.; Dacheux, N. Coffinite, $\mathrm{USiO}_{4}$, Is Abundant in Nature: So Why Is It So Difficult to Synthesize? Inorg. Chem. 2015, 54 (14), 6687-6696. https://doi.org/10.1021/ic502808n.

(105) Konings, R. J. M.; Beneš, O.; Kovács, A.; Manara, D.; Sedmidubskỳ, D.; Gorokhov, L.; Iorish, V. S.; Yungman, V.; Shenyavskaya, E.; Osina, E. The Thermodynamic Properties of the FElements and Their Compounds: Part 2. The Lanthanide and Actinide Oxides. J. Phys. Chem. Ref. Data 2014, 43 (1). https://doi.org/10.1063/1.4825256.

(106) Dorogova, M.; Navrotsky, A.; Boatner, L. A. Enthalpies of Formation of Rare Earth Orthovanadates, $\mathrm{REVO}_{4} . \quad$ J. Solid State Chem. 2007, 180 (3), 847-851. https://doi.org/10.1016/j.jssc.2006.12.001.

(107) Polinski, M. J.; Garner, E. B.; Maurice, R.; Planas, N.; Stritzinger, J. T.; Parker, T. G.; Cross, J. N.; Green, T. D.; Alekseev, E. V.; Van Cleve, S. M.; Depmeier, W.; Gagliardi, L.; Shatruk, M.; Knappenberger, K.L.; Liu, G.; Skanthakumar, S.; Soderholm, L.; Dixon, D.A.; Albrecht-Schmitt, T.E. Unusual Structure, Bonding and Properties in a Californium Borate. Nat. Chem. 2014, 6 (5), 387-392. https://doi.org/10.1038/nchem.1896.

(108) Mazeina, L.; Ushakov, S. V.; Navrotsky, A.; Boatner, L. A. Formation Enthalpy of $\mathrm{ThSiO}_{4}$ and Enthalpy of the Thorite $\rightarrow$ Huttonite Phase Transition. Geochim. Cosmochim. Acta 2005, 69 (19), 4675-4683. https://doi.org/10.1016/j.gca.2005.03.053.

(109) Estevenon, P.; Kaczmarek, T.; Rafiuddin, M. R.; Welcomme, E.; Szenknect, S.; Mesbah, A.; Moisy, P.; Poinssot, C.; Dacheux, N. Soft Hydrothermal Synthesis of Hafnon, $\mathrm{HfSiO}_{4}$. Cryst. Growth Des. 2020. https://doi.org/10.1021/acs.cgd.9b01546.

(110) Suchanek, W. L.; Riman, R. E. Hydrothermal Synthesis of Advanced Ceramic Powders. Adv. Sci. Technol. 2006, 45, 184-193.

(111) Weber, W. J.; Ewing, R. C.; Catlow, C. R. A.; Diaz De La Rubia, T.; Hobbs, L. W.; Kinoshita, C.; Matzke, H.; Motta, A. T.; Nastasi, M.; Salje, E. K. H.; Vance, E.R.; Zinkle, S.J. Radiation Effects in Crystalline Ceramics for the Immobilization of High-Level Nuclear Waste and Plutonium. J. Mater. Res. 1998, 13 (6), 1434-1484. https://doi.org/10.1557/JMR.1998.0205. (112) Weber, W. J.; Ewing, R. C.; Wang, L. M. The Radiation-Induced Crystalline-to-Amorphous Transition in Zircon. J. Mater. Res. 1994, 9 (3), 688-698. https://doi.org/10.1557/JMR.1994.0688. (113) Murakami, T.; Chakoumakos, B. C.; Ewing, R. C.; Lumpkin, G. R.; Weber, W. J. AlphaDecay Event Damage in Zircon. Am. Mineral. 1991, 76, 1510-1532.

(114) Ewing, R. C. Displaced by Radiation. Nature 2007, 445 (January).

(115) Weber, W. J. Self-Radiation Damage and Recovery in Pu-Doped Zircon. Radiat. Eff. Defects Solids 1991, 115 (4), 341-349. https://doi.org/10.1080/10420159108220580.

(116) Farnan, I.; Cho, H.; Weber, W. J. Quantification of Actinide $\alpha$-Radiation Damage in Minerals and Ceramics. Nature 2007, 445 (7124), 190-193. https://doi.org/10.1038/nature05425.

(117) Robie, Richard A.;Hemingway, B. S. Thermodynamic Properties of Minerals and Related Substances at $298.15 \mathrm{~K}$ and 1 Bar ( 105 Pascals) Pressure and at Higher Temperatures. U.S. Geol. Surv. Bull. 1995, 2131.

(118) Navrotsky, A.; Ushakov, S. V. Materials Fundamentals of Gate Dielectrics; 2005. https://doi.org/10.1007/1-4020-3078-9. 
